\title{
Intellectual Capital and Innovation Performance: Empirical Evidence in the Turkish Automotive Supplier
}

\author{
Muammer Zerenler (I), Selcuk Burak Hasiloglu (2), \\ Mete Sezgin (3)
}

\begin{abstract}
The purpose of this study was to investigate the influence of intellectual capital of Turkish automotive supplier industry upon their innovation performance. This study showed that three types of intellectual capital-employee capital, structural capital, and customer capital- had a significantly positive relationship with innovation performance. Moreover, the results also indicated that the higher the growth rate of an industry, the stronger were the positive relationships between three types of intellectual capital and innovation performance. Besides, customer capital was the greatest among these three types of intellectual capital in Turkish automotive supplier industry, employee capital was the next, and structural capital was the least. This shows two points; first, Turkish automotive supplier industry emphasized the interactive "relations" with their suppliers, clients, and partners; second, it was imperative for Turkish manufacturing enterprises to develop their structural capital to increase their innovation performance.
\end{abstract}

Keywords: Intellectual capital; innovation; Turkish automotive supplier.

(I) Assistant Proffesor of Marketing, Faculty of Economic and Administrative Sciences, University of Selcuk, Konya 42079, Turkey. muammerz@hotmail.com.+0090 3322233034

(2) Assistant Proffesor of Marketing, Faculty of Economic and Administrative Sciences, University of Pamukkale, Denizli 20070, Turkey. selcukburak@hasiloglu.com. +00902582952705

Academic visitor of Informatics Research Centre, Business School, University of Reading, RG66BX, UK.

s.b.hasiloglu@reading.ac.uk.+0044 I I83784409

(3) Assistant Proffesor of Tourism and Hotel Management, Vocational School of Social Sciences, University of Selcuk, Konya 42079, Turkey.

metesezgin@hotmail.com.+0090 3322232299 


\section{Introduction}

Global competition and the ever-changing nature of innovation and creativity as a critical factor, force business enterprise to create or transfer new values or bring out new dimensions in addition to the current ones. These obligations also require the complete metamorphosis of present structures, perceptions, and approaches in management and organizational atmosphere. One of the tools making this metamorphosis possible is the acquired intellectual capital.

The age of information directs business enterprises to acquire a data-based and nonmaterial wealth rather than a physical one. This orientation has emerged as a result of experienced facts such as increasing significance of customer service demand in total demand and increasing role of information among production factors. The most outstanding reflection of information age on business enterprises is the importance of the development and effectiveness of data-based accumulation, created by a business enterprise on its activities. In this sense intellectual capital is now regarded as a strategic element in business enterprises nowadays.

According to a research, conducted by Brookings Institution in 1982, while the properties of business enterprises (such as land, factory and supplies) form $62 \%$ of enterprise value, today this rate has gone down to $30 \%$ (Teece, 2000:42).According to the study through which Boulton et al. (2000) have compared the ledger value with market value of 3 enterprises in a 20 years period; while the ledger value of enterprises formed nearly $95 \%$ of its market value, it is has been observed that this rate has gone down to $28 \%$ (Boulton et al., 2000:44). In a research, made on the executives of top 500 enterprises in the U.S.A. and Canada in the year of 2000 , it has been determined that these executives consider the 'data' and 'intellectual capital' as the most strategic source of an enterprise (Dzinkowski, 2000:324).

\section{Intellectual Capital}

Some decomposition is seen in defining the concept of 'intellectual capital' which considers the non-material wealth in a broader perspective, determining its scope and components, managing and reporting it. For instance, definitions such as total of the things, acknowledged by the people in an enterprise and helping it gain sur-petition (Stewart, 1997:24); data value of an enterprise (Walsh, 1991:58); intellectual riches such as data, information, intellectual property and experiences, which can be utilized to gain wealth (Rivette, 2000:168); recorded data of an enterprise and knowledge, skill and experiences of the employees in it as the non-sensorial and invisible properties (Klein, 1998:39) interpret the intellectual capital differently with re- spect to its scope. Stewart (1997:72) defines the intellectual capital as the data of an enterprise, which can be utilized to create extra advantages or the total of the things, acknowledged by the people in an enterprise and helping it gain sur-petition in other words; however, Marr (2005:I I) explains it as the intellectual material, formalized, owned and activated to produce more valuable property. According to Brooking (1997:364), intellectual capital is the discrimination/gap between the ledger value of an enterprise and the value, which is determined to pay for it.

There are various definitions of intellectual capital in the literature. Stewart (1997) defined intellectual capital as the total stocks of the collective knowledge, information, technologies, intellectual property rights, experience, organization learning and competence, team communication systems, customer relations, and brands that are able to create values for a firm. Moreover, intellectual capital was also defined as the total stocks of all intangible assets and capabilities in a company, which can create values or competitive advantages (Edvinsson and Malone, 1997; Stewart, 1997). In addition, the disclosure of intellectual capital can be referred to as supplementary information to the financial statements of a company. Therefore, the concept of intellectual capital can bring a revolution to the traditional accounting system (Edvinsson and Malone, 1997; Stewart, 1997).

There are different views about determining the component of intellectual capital in the article concerned. Edvinsson (1997) explains that intellectual capital consists of human, structural and customer capitals. However, Bontis (1999:435) investigates it as three different components: such as human, structural, and relational capitals. Edvinsson (1997)'s categorization of capital is seen in Figure I.

Generally the components forming the intellectual capital may be listed as employee, structural, and customer capital.

Employee Capital: Employee capital' is different from the more familiar term "human resources", although it has often been used interchangeably with human resource (Edvinsson and Malone, 1999; LeBlanc et al., 2000). "Human resource" implies that workers are not merely cost or expenses to be minimized, but a precious resource that companies must treasure. The term "employee capital" points to the concept that human are not merely resources which companies must treasure, but also are "capital" that can be invested to yield income and other useful outputs over long periods of time (Becker, 1975).

The goal of enterprises is to possess own employee capital on a rate it can be utilized as profitable. For that reason, employee capital has been created and used only if the employees of an 


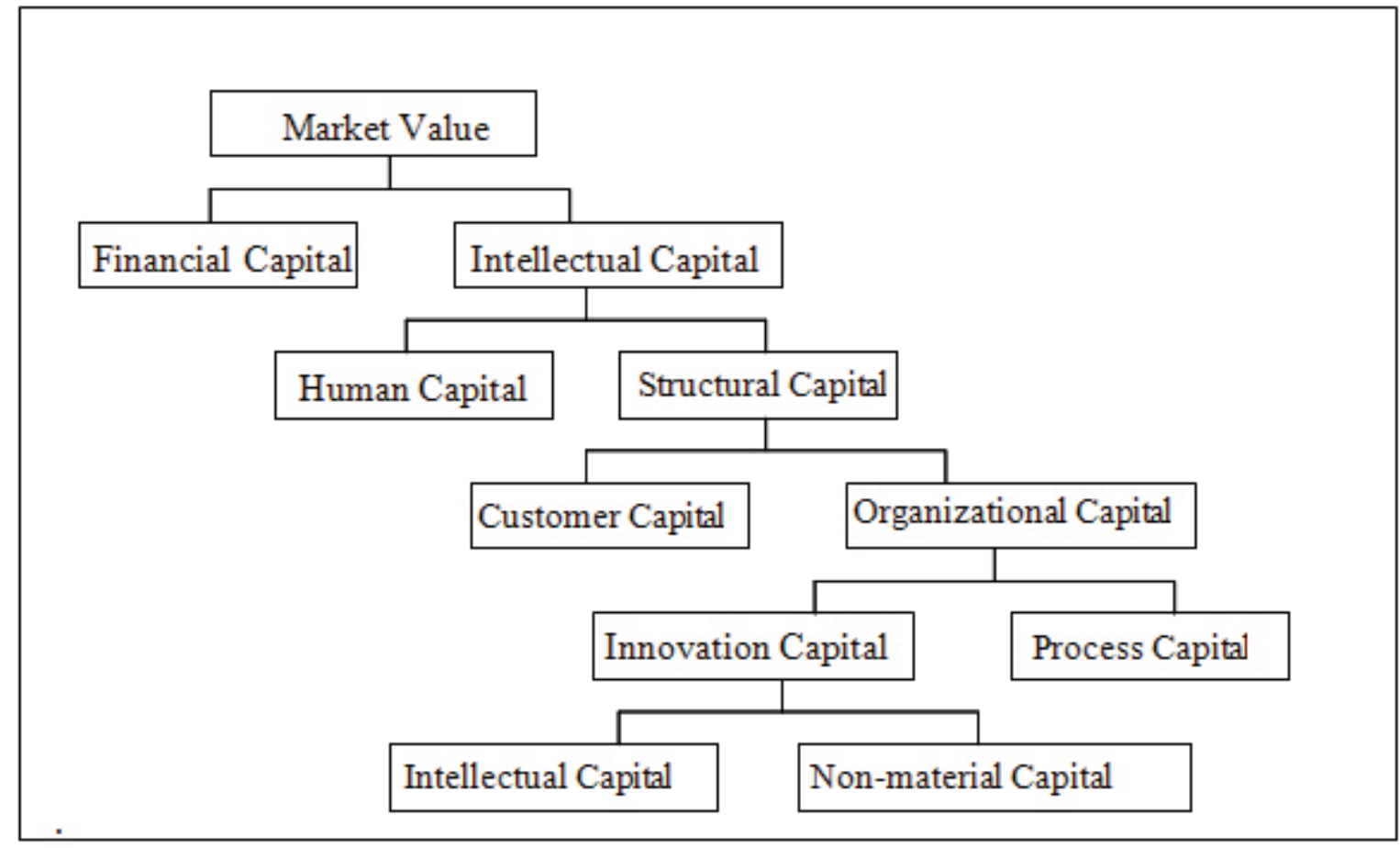

Figure I. Edvinsson's Categorization of Capital

Resource: Leif Edvinsson and M. S. Malone, “Intellectual Capital: Realizing Your Company's True Value by Finding Its Hidden Brainpower”, Harper Business, New York, 1997.

enterprise could direct their time and skills mostly to innovative activities (Stewart, 1997:95). In this sense, employee capital is the total of the experiences, skills and capabilities of executives and employees (Edvinsson and Malone, 1997:34). Stewart (1997:94) considers employee capital as the source of organizational culture and innovation. Development of this capital can be possible through considering the ideas of employees and listening to their suggestions to develop the business. It is possible to enlist the component of employee capital, which is also considered as the corporate capability of an enterprise, in the sense of benefiting from the acquired knowledge of the people in its body, as mentioned below (Guthrie, 2001:35);

- Know-How

- Training

- Professional Adequacy

- Studies Aimed at Data Production

- Studies Aimed at Forming Capability/Skill,

- The Joy of Entrepreneurship, Invention, Accepting and Rejecting Skills and Revolutionism.
Structural Capital: It is the total of systematical studies, aimed at providing a lever by making the knowledge and skill, which are stated as the employee capital, institutional and forming an united organizational memory (Andriessen, 200 I:I03). Every enterprise has its own unique structural capital (Klein, 1998:6I). All of the immovable components/properties of an enterprise unite the structural capital and hardware, software, database, organizational structure, patents and trademarks form the structural capital.

Customer Capital: Customer capital puts forward the value of the relationship of an enterprise with customers, suppliers and the rest of the society for consideration and states the loyalty of mentioned ones to the enterprise (Chwalowski, 1997:89). In addition to that, any enterprise with a customer has a customer capital. Among all intellectual properties, customer capital has the most outstanding value. Mouritsen et al (200I:36I) define this capital as the title value of an enterprise, continuing relationships of it with the buyer persons and organizations.

\section{Innovation Performance}

Over the last two decades the relationship between innovation and geography has become an important theme for research into economic growth. While the links between innovation and 
growth have long been discussed (Nelson and Winter, 1982), more recently the work of Porter (1990), Scott (I988), Acs (2002) has focused attention on the ways in which localized knowledge and technology spillovers may promote innovation.

In particular, it is argued that face-to-face contact between local firms and organizations promotes knowledge exchanges, which in turn are assumed to facilitate innovation (Storper and Venables, 2004). However, knowledge can also be transferred by the movement of human capital embodied in labor mobility. Yet, the type of knowledge transfers associated with labor mobility are largely absent from the innovation literature within urban economics. Little is therefore known about the importance for innovation of human capital mobility.

\section{Intellectual Capital \& Innovation Performance Integration}

The distinctive competence of a company can generate better managerial effectiveness, operation efficiency, and innovation than its competitors, and can further provide more value and benefit for its customers (Hill and Jones, 200I). On the other hand, the more intellectual capital of a company is, the more distinctive is the unique competence of the company, the better (Edvinsson and Malone, 1997). Moreover, the more the unique competence of the company is, the better innovation performance can be achieved (Garcia and Calantone, 2002). The distinctive competence of the company can be regarded as the result of intellectual capital within the firm. Hence, when a company has more intellectual capital, it would create better innovation performance. In other words, when a company has more intellectual capital, it would have more innovative competence to further increase its new product development performance. Namely, there is obviously positive correlation between the existing intellectual capital within the organization and its innovation performance.

Intellectual capital in this study was defined as the total stocks of all kinds of intangible assets, knowledge, capabilities, and relationships, etc, at employee level and organization level, within a company. This study referred to literatures of the past and classified intellectual capital into employee capital, structural capital, and customer capital (Bontis, 1999). "Employee capital" in this study was defined as the summation of employees' knowledge, skills, capabilities, experience, attitude, wisdom, creativities, and commitment, etc and was embedded in employees, not organizations. A company can increase its innovation performance through its employee capital. In this research,"structural capital" was defined as the stocks of organizational capabilities, organizational commitment, knowledge management systems, reward systems, information technology systems, databases, managerial institution, operation processes, manage- rial philosophies, organizational culture, company images, patents, copyrights, and trademarks, etc, within a company; it is embedded in organizations, and thereby cannot be taken away by employees. Structural capital might best be described as the supportive infrastructure of employee capital.Therefore, a company can enhance its innovation performance through its structural capital."Customer capital" in this study was defined as the stocks of connections, interactions, relationships, linkages, closeness, goodwill, and loyalty between a firm and its customer downstream clients, strategic partners or other external stakeholders. A company can gain important information or support about innovation form its suppliers, clients, strategic partners, or other external stakeholders. Therefore, a company can enhance its innovation performance through its customer capital. If a firm has more intellectual capital, it would have better performance on innovation. Hence, this study implied the following hypotheses:

$\mathrm{HI}$ : Intellectual capital is positively associated with innovation performance in automotive supplier industry.

Moreover, the study divided intellectual capital into three types: employee capital, structural capital, and customer capital. We analyzed that these three types of intellectual capital are positively associated with innovation performance as follows. In the era of knowledge economy, employee capital, which would dominate the growth of a firm, is one of the important assets for its future development. Moreover, there exists a positive relationship between employee capital and innovation (Dakhli and De Clercq, 2004). Furthermore, the excellent experiences, professional skills, creativities, managerial capabilities, and specialties, etc of employees, project leaders, and senior managers of innovation projects in a firm have a positive effect on its innovation performance (Barczak and Wilemon, 2003). On the other hand, previous researchers postulated that the innovation mindset of individuals should be stimulated because it is helpful for firms' innovation and new product development (Kuczmarski, 1996). Thus, we posited that employee capital has a positive effect on innovation performance. Hence, this study implied the following hypothesis:

$\mathrm{H} 2$ : Employee capital is positively associated with innovation performance in automotive supplier industry.

Modern marketplaces are characterized by speedy technological breakthroughs, rapid changes in social conditions and consumer needs, and shrinking product life cycles. Consequently, companies must consider strategies to enhance their innovation performance. Previous researchers argued that the managerial systems and operation processes of a firm to create value-added activities associated with shrinking its innovation development cycles and the infrastructural characteristics (or- 
ganizational design, and systems of knowledge management) and procedural factors (operation processes, and systems of controls and incentives) would positively influence its innovation skills (Menona et al., 2002). On the other hand, recent researches suggested that firms' culture and organizational commitment of sufficient resources have an important impact on the performance of its innovation (de Brentani and Kleinschmidt, 2004). Moreover, the dynamic organizational capabilities, such as excellent management systems, operation procedures, and the processes of the knowledge management, propel firms' value creation activities that have a positive effect on their innovation skills (Marsh and Stock, 2003). Therefore, we asserted that there exists the positive relationship between structural capital and innovation performance. Consequently, this study implied the following hypothesis:

H3: Structural capital is positively associated with innovation performance in automotive supplier industry.

As the relational literatures suggest, involving customers who have had close and embedded relationships with a firm should lead to the development of superior products. These close customers provided innovation projects with a diversity of perspectives, competencies, and experiences that fostered significant product and process innovations (Bonner and Walker, 2004). In addition, many manufacturing firms are becoming involved in closer relationships with their suppliers in order to utilize their skills, capabilities, information, and resources to develop new products faster and at less cost so that closer relationships with suppliers have a positive influence upon firms' innovation performance (Walter, 2003). Furthermore, firms' strategic communities, including external customers, suppliers, and other partners are helpful to achieve the desired innovation performance (Capello and Faggian, 2005). Thereby, we postulated that customer capital has a positive influence upon innovation performance. Thus, this study implied the following hypothesis:

H4: Customer capital is positively associated with innovation performance in automotive supplier industry.

\section{Methodology and Measurement}

\section{Data Collection and Samples}

This study tested hypotheses with a questionnaire survey that was conducted in Turkish manufacturing companies. The industry is concentrated in clusters in the Marmara Region, mainly in Bursa in two Organised Industrial Zones. There are also two major car factories in the Province. Other important Provinces which clusters are established are Istanbul, Izmir, Kocaeli, Ankara, Konya, Adana and Manisa. Recently by the initiative of
TAYSAD (Association of Automotive Parts and Components Manufacturers),TAYSAD Component Manufacturers Industrial Zone has been established in Kocaeli. The Zone covers 2.500 hectares and provides TAYSAD members larger production sites, modern environmental facilities, proximity to vehicle manufacturers, training and conference facilities, inter-firm cooperation and a technology and innovation center. TAYSAD, the Manufacturers Association is very efficient in clustering network activities. It has very strong ties with the public institutions and with its members. It was established in Istanbul in 1978. With its 180 members, it represents $65 \%$ of the output of the automotive supplier industry and $70 \%$ of the industry's exports. $87 \%$ of its members operate in the Marmara region. 180 members employ a total of 40,000 people. Including the suppliers of its members, the total number of employees reaches approximately $80,000.35$ members of it have foreign partners (Bedir, 1999).

The data for this study was collected throughout a field survey to the automotive suppliers located in TAYSAD Component Manufacturers Industrial Zone. The names and addresses of the companies were obtained from the TAYSAD Database.The survey was made from April 2008. The respondents of the questionnaires were the managers of the marketing department, R\&D department, or production department relating to innovation. To increase the valid survey response rate, we called each company that was sampled, explained the objectives of the study and the questionnaire content, and confirmed the names and job titles of the respondents prior to questionnaire mailing. The respondents were asked to return the completed questionnaires within two weeks through mailing.

The study referred to the past literatures in order to design questionnaire items for the survey. Prior to mailing to the respondents, three experts and scholars were asked to modify the questionnaire in the first pretest. Subsequently, the questionnaires were randomly mailed to ten managers in the marketing department, R\&D department, or production department of different companies, and they were asked to fill in the questionnaires and identify ambiguities in terms, meanings, and issues in the second pretest. The questionnaire therefore had a high level of content validity. I I 7 questionnaires were sent to the managers of the marketing department, R\&D department, or production department.

There were 92 responses, which included 76 valid questionnaires and 16 invalid ones. The effective response rate was $78.63 \%$.

\section{Variable Definition and Measurement}

The measurement of the questionnaire items in this study was 


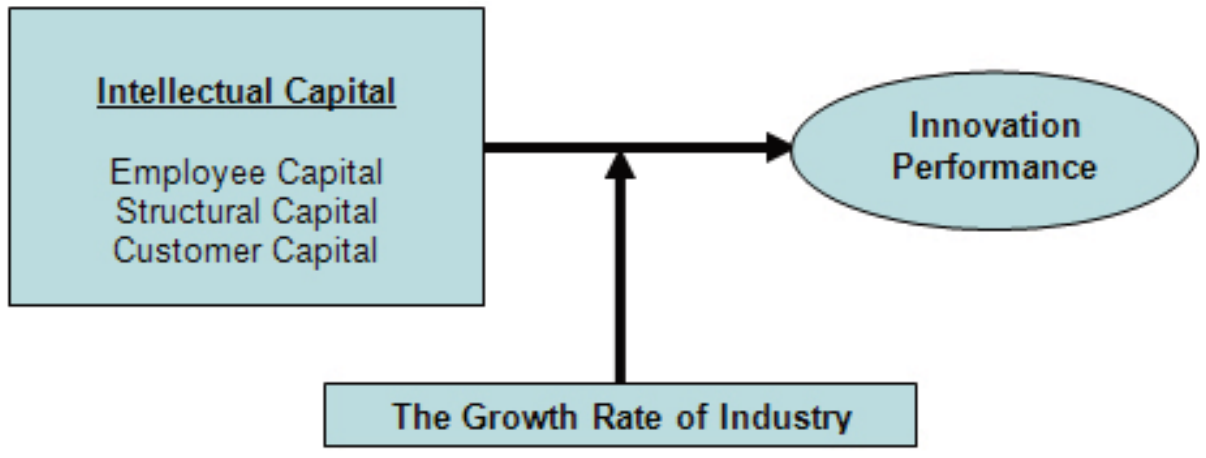

\section{Figure 2. Research Framework}

with a 'five-point Likert scale from I to 5' rating from strongly disagree, disagree, neutral (neither disagree nor agree), agree, and strongly agree. The questionnaire comprised three parts. The first part of the questionnaire consisted of the descriptive data of the company (including the number of employees, year founded, industry sector, etc; if a company's business covered more than one industry, the firm was classified into the industry whose sales were the most among these ten manufacturing industries), the second part was the measurement of intellectual capital (including employee capital, structural capital, and customer capital), and the third part the measurement of innovation performance.

The definitions and measurements of the constructs were further defined as follows. Intellectual Capital: Intellectual capital in this study was defined as the total stocks of all kinds of intangible assets, knowledge, capabilities, and relationships, etc, at employee level and organization level within a company, and can most commonly be split into three types: human capital, structural capital, and relational capital (Johnson, 1999; Bontis, 1999; Bozbura, 2004). Employee capital in this study was defined as the summation of employees' knowledge, skills, capabilities, experience, attitude, wisdom, creativities, and commitment, etc, and was embedded in employees not in organizations.

Structural capital in this study was defined as the stocks of organizational capabilities, organizational commitment, knowledge management systems, reward systems, information technology systems, databases, managerial institution, operation processes, managerial philosophy, organizational culture, company images, patents, copyrights, and trademarks, and so on, within a company. Customer capital in this study was defined as the stocks of connections, interactions, relationships, linkages, closeness, goodwill, and loyalty between a firm and its customers, upstream suppliers, downstream clients, strategic partners, or other external stakeholders. Referring to the past literatures, intellectual capital including employees' capabilities and knowledge, systems and processes of firms, and their external relationships could enhance their competencies and create their fortunes and values. Moreover, the study classified intellectual capital into human capital, structural capital, and relational capital (Johnson, 1999; Bontis, 1999; Bozbura, 2004).

Innovation Performance:A review of past research on organizational innovation also indicates that there have been variations in measuring innovation performance in organizations. For the purpose of comprehensively capturing the aspects of innovation performance, this study built the construct for measuring product and process innovation on the basis of several criteria which are conceptualized and used in previous empirical studies of innovation, such as Avlonitis et al. (1994:24), Deshpande et al. (1993:I I), Miller and Friesen (1982:17), and Subramanian and Nilakanta (1996:638). These criteria are the number of innovations, the speed of innovation, the level of innovativeness (novelty or newness of the technological aspect), and being the 'first' in the market. By including the last two criteria, the scope of the innovation performance measures captured areas that could be considered as "radical" innovation. These four characteristics of innovation were applied in two major areas of innovation, namely product innovation and process innovation. Conceptually, product innovation is concerned with generating ideas or the creation of something entirely new that is reflected in changes in the end product or service offered by the organization, while process innovation represents changes in the way firms produce end products or services through the diffusion or adoption of an innovation developed elsewhere. The distinction between these two areas of innovation has been articulated in the literature on innovation.

The Growth Rate of the Industry: As the scale of an industry was usually defined as the total sales in the industry, this study defined the growth rate of the industry as the growth rate of the total annual sales in the industry. The annual growth rates of the ten manufacturing industries were referred to the archival data, which were listed in the Industrial Development Yearbook, published by Institute of State Statistic of Turkish during the periods from 200I to 2007. The growth rates of the automotive supplier industry respectively indicated $29.00 \%$ in the 
automotive industry. Because the 'Industrial Development Yearbook' had compiled the growth rates of the automotive supplier industry, this study excluded the measurement of the growth rate of the industry from the questionnaire.

\section{Empirical Results}

Table I showed correlation coefficients between constructs. It can be found from Table I that innovation performance had obviously positive correlations with employee capital, structural capital, and customer capital respectively, whereas there did not exist other significant correlations between other constructs. There existed partial positive correlations between employee capital, structural capital, and customer capital, but they were not significant.

\section{Table I. Correlation coefficients between constructs}

\begin{tabular}{|l|c|c|c|c|c|}
\hline & A & B & C & D & E \\
\hline Employee capital & & & & & \\
\hline Structural capital & 0.328 & & & & \\
\hline Customer capital & 0.321 & 0.311 & & & \\
\hline $\begin{array}{l}\text { The growth rate of the } \\
\text { industry }\end{array}$ & 0.163 & 0.114 & 0.145 & & \\
\hline Innovation performance & $0.347^{* *}$ & $0.469^{* *}$ & $0.361^{* *}$ & 0.083 & \\
\hline
\end{tabular}

Note: $p<0.1,{ }^{*} p<0.05, * p<0.01$

The study applied regression analysis to verify the hypotheses. It can be found from Model I and Model II in Table 3 that three types of intellectual capital, i.e. employee capital, structural capital, and customer capital, had significantly positive relationships with innovation performance. That meant the more significant were the three types of intellectual capital within a firm, the better its innovation performance.

Therefore, the hypotheses of $\mathrm{H} 2, \mathrm{H} 3$, and $\mathrm{H} 4$ were significantly supported. In addition, the study tested the interaction terms between three types of intellectual capital - i.e. employee capital, structural capital, and customer capital - with the growth rate of the industry in Model II to verify whether there existed the moderation effect from the growth rate of the industry. Moreover, Model II in Table 2 showed that the interaction terms between the growth rate of the industry and the three types of intellectual capital - i.e. employee capital, structural capital, and customer capital - were significant; in other words the growth rate of the industry indeed had an obvious moderation effect on the relationships between three types of intellectual capital and innovation performance. It meant that the higher the growth rate of automotive supplier industry, the stronger were the positive relationships between three types of intellectual capital and innovation performance.

\section{Table 2. Empirical results of regression analysis}

\begin{tabular}{|c|c|c|}
\hline Dependent variable & Model I & Model II \\
\hline $\begin{array}{l}\text { Control variable } \\
\text { Log (number of employees) }\end{array}$ & $0.172(1.689)$ & $0.168(1.625)$ \\
\hline $\begin{array}{l}\text { Independent variables } \\
\text { Employee capital } \\
\text { Structural capital } \\
\text { Customer capital }\end{array}$ & $\begin{array}{lc}0.258^{*} & (3.164) \\
0.369^{* *} & (4.582) \\
0.288^{* *} & (4.135)\end{array}$ & $\begin{array}{l}0.223^{*}(1.647) \\
0.346 *(3.142) \\
0.241^{*}(2.326)\end{array}$ \\
\hline $\begin{array}{l}\text { Interaction terms } \\
\text { Employee capital } X \text { The growth rate of the industry } \\
\text { Structural capital } X \text { The growth rate of the industry }\end{array}$ & & $\begin{array}{l}0.226 *(1.763) \\
0.237 *(2.348) \\
0.246 *(2.214)\end{array}$ \\
\hline Customer capital X The growth rate of the industry & & \\
\hline Adjusted $\mathrm{R}^{2}$ & 0.412 & 0.448 \\
\hline $\mathrm{N}$ & 92 & 92 \\
\hline $\mathrm{F}$ & $69.916 \%$ & $41.116 \%$ \\
\hline
\end{tabular}

Note: The number in the bracket is the t value. $\mathrm{p}<0.1,{ }^{*} \mathrm{p}<0.05,{ }^{*} \mathrm{p}<0.01$ 
Subsequently, the study applied the paired test to analyse whether there were differences between the three types of intellectual capital - employee capital, structural capital, and customer capital - in automotive supplier in Turkish. Table 3 shows that there were obvious differences between the three types of intellectual capital. The results show that customer capital was the most significant among these three types of intellectual capital in Turkish automotive supplier companies, employee capital was next, and structural capital was the least significant.This indicated two things: first, automotive suppliers in Turkish emphasized the interactive 'relationships' with their customers, upstream suppliers, downstream clients, and strategic partners; second, it can be observed from Table 2 that structural capital had a significantly positive relationship with innovation performance; nevertheless, the least significant capital among the three types of intellectual capital was structural capital.

\section{Table 3. Paired t test between employee capital, structural capital and customer capital}

\begin{tabular}{|l|c|c|c|c|}
\hline & Mean & A-B & B-C & C-A \\
\hline $\begin{array}{l}\text { Mean of employee capital } \\
\text { (A) }\end{array}$ & 3.6724 & $0.1841(5.245)^{* *}$ & $-0.5176(-8.824)^{* *}$ & $0.1894(5.387)^{* *}$ \\
\hline $\begin{array}{l}\text { Mean of structural capital } \\
\text { (B) }\end{array}$ & 3.4827 & & & \\
\hline $\begin{array}{l}\text { Mean of customer capital } \\
\text { (C) }\end{array}$ & 3.865 & & & \\
\hline
\end{tabular}

Note: The measurement of the questionnaire items in this study was with a five-point Likert scale from I to 5 ,

rating from strongly disagrees, neutral (neither disagree nor agree), agree, and strongly agree. Number in the

sample $n: 92$, the number in the brackets is the $t$ value $p<0.1,{ }^{*}<<0.05,{ }^{*} p<0.01$.

\section{Discussion}

In recent years, intellectual capital has attracted much attention from scholars, enterprises, and governments in practical applications and further discussion. However, we found there were no relevant studies exploring the relationship between intellectual capital and innovation performance, so this study focused on this research gap.

The study explored the influence of three types of intellectual capital, i.e. employee capital, structural capital, and customer capital, on innovation performance. Moreover, the study regarded the growth rate of the automotive supplier industry as a moderator to explore whether the positive relationships between intellectual capital and innovation performance are stronger or not when the growth rate of the industry is higher.

This study tested hypotheses with a questionnaire survey and was conducted in Turkish automotive supplier industry. Moreover, the purpose of this study was to explore the influence of intellectual capital upon innovation performance of Turkish automotive supplier industry. One of the main conclusions from this study was that the three types of intellectual capital had obviously positive relationships with innovation performance.

This study analysed three types of intellectual capital - em- ployee capital, structural capital, and customer capital - in Turkish and calculated their mean values, respectively, as a reference for managers in Turkish to evaluate their intellectual capital. Moreover managers of enterprises in Turkish can refer to the questionnaire items of this study to evaluate the strength and weakness of their intellectual capital, so as to carry out subsequent improvement. Innovation development is an important approach to position the image of a corporation in a market. We hope that this study can provide measurable indicators of intellectual capital for investors as a useful tool to evaluate the performance of companies beyond financial statements.

\section{References}

ACS, Z. (2002). Innovation and the Growth of Cities, Cheltenham: Edward Elgar.

ANDRIESSEN, D. (200I). Making Sense of Intellectual Capital, New York: Elsevier.

AVLONITIS, G.J., Kouremenos, A., Tzokas, N. (1994). Assessing the innovativeness of organizations and its antecedents: project innovstrat. European Journal of Marketing, V.28(I I), 5-28.

BARCZAK, G. \& Wilemon, D. (2003). Team Member Experiences in New Product Development: Views from the 
Trenches. R\&D Management,V.33(5), 463-479.

BECKER, G.S. (1975) Human Capital. New York: Columbia University Press.

BEDIR,A. ( I 999). Gelismis Otomotiv Sanayilerinde Ana-Yan Sanayi Iliskileri ve Turkiye'de Otomotiv Yan Sanayinin Gelecegi (Assemblersupplier Relation in the Developed Automotive Industry and The Future of Automotive Supplier Industry' in Turkey) (in Turkish), Ankara: State Planning Organization, No: 2495.

BONNER, J.M. \& Walker, O.C. (2004). Selecting influential business-to-business customers in new product development: relational embeddedness and knowledge heterogeneity considerations, Journal of Product Innovation Management, V.2I, 155-169.

BONTIS, N. (1998). Intellectual capital: an exploratory study that develops measures and models. Management Decision,V.36, No.2, 63-76.

BONTIS, N. (1999). Managing Organizational Knowledge by Diagnosing Intellectual Capital: Framing and Advancing the State of the Field. International Journal of Technology Management, $18,5-8,433-462$.

BOULTON, R., Libert, B. \& Samak, S. (2000). Cracking the Value Code. How Successful Businesses are Creating Wealth in the New Economy, NY: Harper Collins.

BOZBURA, F. T. (2004). Measurement and Application of Intellectual Capital in Turkey. Learning Organization, V. I I (4/5), 357-367

BROOKİNG,A. (1997). Intellectual Capital. London: International Thomson Business Press.

CAPELLO, R. \& Faggian,A. (2005) Collective learning and relational capital in local innovation processes, Regional Studies, V.39 , 75-87.

CHOO, C. \& Bontis, N. (2002). The Strategic Management of Intellectual Capital and Organizational Knowledge. Oxford: Oxford University Press.

CHWALOWSKI, M. (1997). Intellectual Capital Matters!. The Electricity Journal, V.I0, No. I0, 88-93.

DAKHLI, M., \& De Clercq, D. (2004). Human capital, social capital, and innovation: a multi-country study. Entrepreneurship \& Regional Development, V.16, I07-128.
DE BRENTANI, U. \& Kleinschmidt, E.J. (2004) Corporate Culture and Commitment: Impact on Performance of International New Product Development Programs. Journal of Product Innovation Management, V.2I (5), 309-333

DESHPANDE, R., Farley, J.U.,Webster Jr F.E. ( I 993). Corporate culture customer orientation and innovativeness in Japanese firms: a quadrad analysis. Journal of Marketing, V.57( I), 23-29.

DIAMANTOPOULOS, A. \& Inglis, K. (1988). Identifying differences between high- and low involvement exporters. International Marketing Review, V.5(2), 52-60.

DZINKOWSKI, R. (2000). The Measurement and Management of Intellectual Capital:An Introduction. International Management Accounting, Vol:78, No:2, I68-183.

EDVINSSON, L. \& Malone, M. S. (1997). Intellectual Capital:Realizing Your Company's True Value By Finding Its Hidden Brainpower. New York: Harper Business.

EDVINSSON, L. (1997). Developing intellectual capital at Skandia. Long Range Planning. 30(3), 366-373.

EDVINSSON, L., Dvir, R., Roth, N. \& Pasher, E. (2004). Innovations: the new unit of analysis in the knowledge era The quest and context for innovation efficiency and amangement of IC. Journal of Intellectual Capital. 5(I), 40-48.

GARCIA, R. \& Calantone, R.J. (2002). A Critical Look at Technological Innovation Typology and Innovativeness Terminology: a Literature Review. Journal of Product Innovation Management, Vol. I9 (2), I I0-I32.

GUTHERIE, J., Johanson, U., Bukh, P. N., \& Sanchez, P. (2003). Intangibles and the transuppliernt enterprise: new strands of knowledge. Journal of Intellectual Capital,.V.4(4), 429-440.

GUTHRIE, J. (200I). The Management, Measurement and the Reporting of Intellectual Capital. Journal of Intellectual Capital, Cilt.2, Sayı: I, 24-4I.

HILL, C.W.L. \& Jones, G.R. (200I). Strategic Management Theory - An Integrated Approach, Boston, New York: Houghton Mifflin Company.

http://www.taysad.org.tr/altmenu.asp?Anald= | $4 \mid$ I \&def_dil_id= I49 (I3.02.2007)

JOHNSON, W.H.A. (1999). An Integrative Taxonomy of Intellectual Capital: Measuring the Stock and Flow of Intellectual Capital Components in the Firm. International Journal of 
Technology Management,V.18(5-8), 562-575

KLEIN, D.A. (Ed) (1998). The Strategic Management of Intellectual Capital. New York: Butterworth-Heinemann Pub.

KUCZMARRSKI,T.D. (1996). Innovation: Leadership strategies for the competitive edge. NTC Business Books \& American Marketing Association

KUEMMERLE, W. (2002). Home base and knowledge management in international ventures. Journal of Business Venturing, 17(2), 99-122.

MARR, B. (Ed.), (2005). Perspectives on Intellectual Capital. Multidisciplinary Insights into Management, Measurement and Reporting. London: Elsevier.

MARR, B., Gray, D. \& Neely, A. (2003). Why do firms measure their intellectual capital? Journal of Intellectual Capital, 4 (4), 44I464.

MILLER, D. \& Friesen, P.H. (1982). Innovation in conservative and entrepreneurial firms: two models of strategic momentum. Strategic Management Journal,V.3(I), I-25.

MOURITSEN, J., Bukh, P. N., Larsen, H.T. \& Joansen, M.R. (2002). Developing and managing knowledge through intellectual capital statements. Journal of Intellectual Capital, V.3(I), I0-29.

MOURITSEN, J., Larsen, H.T. \& Bukh, P.N. (200I). Reading intellectual capital statements: de scribing and pre scribing knowledge management strategies. Journal of Intellectual Capital, 2 (4), 359-383.

NELSON, R. \& S. Winter (1982). An Evolutionary Theory of Economic Change. Cambridge (MA): Harvard University Press.

PORTER, M.E. (1990). The Comparative Advantage of Nations, Basingstoke/London: Macmillan.

RIVETTE, K. (2000). Discovering New Value in Intellectual Capital. Harvard Business Review, Jan-Feb'00.

RUSSEL, J., Terborg, J. \& Powers M. (1985). Organizational Performance and Organization Level Training and Support. Personnel Psychology, V.38, No:25, 4I-63.

SCOTT,A.J. (1988). New Industrial Spaces, London: Pion.

STEWART, A. T. (I997). Intellectual Capital, The New Wealth of Organizations. New York: Bantam Doubleday Publishing.
STORPER, M. \& Venables,A.J. ( 2004). Buzz: face-to-face contact and the urban economy. Journal of Economic Geography, Oxford University Press, Vol. 4(4), 35 I-370

SUBRAMANIAN, A. \& Nilakanta, S. (1996). Organizational innovativeness: exploring the relationship between organizational determinants of innovation, types of innovations, and measures of organizational performance. Omega,V.24(6), 63I-677.

TEECE, D. J. (2000). Managing Intellectual Capital: Organizational, Strategic, and Policy Dimensions (Clarendon Lectures in Management Studies). NY: Oxforf University Press.

WALSH, J. P. \& Ungson, G. R. (I99I). Organizational Memory. Academy of Management Review, I6(I), 57-9I.

ZHOU, A. Z. \& D. Fink. (2003). The Intellectual capital web. A systematic linking of intellectual capital and knowledge management. Journal of Intellectual Capital, V.4(I), 34-48. 